\title{
Ecotourism: sustainable indigenous policies and its effects in Mayan communities, southern Mexico
}

\author{
S. E. Valle-García \\ Facultad de Ciencias Políticas y Sociales, \\ Universidad Nacional Autónoma de México, México
}

\begin{abstract}
In a sustainable development paradigm, the promotion of alternative tourism seeks simultaneously: preservation of nature, alleviation of poverty and consideration to ancestral culture. Nevertheless, in an analysis of multilateral and federal policies with methodological triangulation of surveys, in-depth interviews and participative observation, about the tourism market's dynamics in the ecotouristic Mayan community of Lacanjá Chansayab Chiapas, it was found that the aims of alternative tourism have not been achieved because the changes from a primary to a tertiary economic sector of indigenous' livelihoods has induced: 1) inter-ethnic struggles over economic natural resource management; 2) upward and downward spiral marginalization; 3) creation of urban environmental problems; 4) ancestral cultures have reconfigured their social function; 5) natural and cultural capitals have become global stock, less favoring indigenous people. The causes are, on the one hand, the intervention of multi-sectorial policies in Mexico is diffuse and without local participation in their design. On the other hand, the absence of impact assessment ex-ante to government interventions.

Keywords: sustainable tourism, poverty and environment, indigenous policies effects, rural and protected areas, socio-spatial transformations.
\end{abstract}

\section{Introduction}

The dominant discourse about sustainability is argued in equally among economic, social and environment systems. The most important activity that achieves the goal is tourism. First, this is because this service economic activity has no direct impact 
on natural resources, and second, it is an activity that can help to alleviate poverty with the Gross Domestic Product (GDP) increment at national level.

In recent years, "Sustainable Development" can be achieved not only through intense nature preservation but also with the high participation of local settlements. For this reason, Sustainable Tourism combines: Protected Natural Areas (PNAs) which are inhabited more by indigenous people in conditions of poverty. Therefore, the activity itself is implied to be the panacea that solves three big objectives: natural and cultural preservation with poverty alleviation [1].

Multilateral and supranational organizations like World Bank, International Monetary Fund, World Wildlife Fund, United Nations Development Programme and UNESCO promote sustainable tourism with international agreement. For this reason, in México the discourse is translated into promotion of services activities, and some farming activities in rural areas, with the implementation of the policies. Nevertheless, the well intentioned goal can be limited by scale factors: a localregional context; the national political system; the global tourism market.

Consequently, in the present paper we will analyze the effects of indigenous policies that promote ecotourism as the solution of economic problems in southern Mexico. More specifically, the dynamic in the Mayan region mainly in the Lacandon rainforest is included as a case study: Lacanjá Chansayab. The document is divided into four sections: 1) sustainable tourism and ecotourism definitions; 2) implementation of Mexican ecotourism policies in rural areas; 3) empirical evidence of "Mayan World" Programme, Lacandon rainforest social dynamic and ecotourism effects in Lacanjá Chansayab; 4) socio-spatial transformation analysis.

\section{Sustainable tourism and ecotourism}

"Alternative tourism" as opposed to "conventional tourism", is a specialized practice developed in nature and promotes the active participation of tourists with a deep interaction with the exotic environment and preserved communities [2]. A ramification of alternative tourism is "low impact tourism" better known as "ecotourism" in the ecosystem and its preservation [3].

This sustainable tourism mode tries to seek the optimal use of natural resources, to preserve the essential ecological process; to respect communities' ancestral traditions and to guarantee the long-term economic benefits to the alleviation of poverty. In this sense, environment refers not only to the natural environment flora, fauna, landforms, and atmospheric considerations - but also to social, economic, scientific, managerial, and political elements [2].

Moreover, it is possible to describe four fundamental elements of ecotourism [1-3]:

1) Travel should be restricted to Protected Natural Areas (PNAs).

2) It is not a business trip or conventional holiday to beach or cities.

3) The travel's interval is related to cultural and environmental awareness, environmental preservation and empowerment of the local people.

4) Includes a learning process about nature and, promotes pro-conservation sentiments and actions. 


\section{Mexican policies and ecotourism}

The Mexican version of sustainable tourism is a mixture of economic activities developed with environmental and indigenous policies. Since the TLCAN Agreement, tourism is seen as a job generator and accelerator of growing economics [4].

This implementation includes multi-sectorial participation at local, regional and multilateral levels. In August 2007, the "General Agreement of Interinstitutional Collaboration for Sustainable Tourism Development in Mexico, 2007-2012" was signed and has as its goal:

"To use and preserve rationality the natural resource with the rural and indigenous development through direct participation and formal employments" [5].

In this sense, sustainable tourism is implemented with work joined to Mexican Secretaries in "Community-Based Sustainable and Heritage Tourism to Rural Development and Conservation Programme" at three levels:

1) Firstly, touristic promotion. The Tourism Secretary (SECTUR) only encourages rural tourism and supports the promotion of places to visit, the touristic infrastructure in communities, and training to indigenous people about touristic services [5].

2) Secondly, tourism with ecological management. The National Commission for Indigenous Communities Development (CDI); and Environment and Natural Resources Secretary (SEMARNAT) are trying to seek nature preservation and community-based alternative tourism through ecotourism certification, the touristic infrastructure with ecological equipment and training to indigenous people $[6,7]$.

3) Thirdly, complement with enhanced social and environmental conditions. The Social Development Secretary (SEDESOL) joined with SEMARNAT in order to seek simultaneously poverty alleviation and nature preservation with Conditional Cash Transfers - payments for Environmental Services (PES) by SEMARNAT and Oportunidades by SEDESOL - ensuring that people do not take natural resources, and complementing with natural resource management (SEMARNAT) and Food Safeguards (SEDESOL) $[6,8]$.

This is followed by international organizations:

1) Social and environmental attention: Agency for International Development (USAID), Organization International for Conservation (Pronatura), and Mexican Found for Nature Conservation A. C (FMCN).

2) The European Union with Sustainable and Social Development Project (Prodesis) and Programme Reducing Emission from Deforestation and Forest Degradation (REDD+plus).

In addition, it is more important that the state government issues subsidies on the one hand, and collaborates with federal actions on the other hand. Nevertheless, tourism in México is not free from contradictions, paradoxes, complexities and disappointments. 


\section{Mayan communities in southern Mexico}

In this section, we will present the empirical evidence of ecotourism policy analysis and its effects in Mayan communities in Southern Mexico. The section is divided into two parts. The first shows hemerographic and bibliographic results of the one hand from the "Mayan World" and the other hand in the Lacandon rainforest.

The second part develops the study case: Lacanjá, Chiapas. Data arising were collected from May to July 2012. It includes an analysis comparative simulating three sceneries: before the people stared to join any governmental programme; during the flow of governmental subsides; and at present, to understand environmental policies' effects in rural communities (micro level) and the change attributable to government intervention (macro level). 18 surveys given to households were conducted for to discover conditions of well-being, and environmental problems.

Likewise, 23 in-depth interviews were implemented to recognize the sociospatial transformation level of individual, family and community. At the same time, participatory observation in a settlement was conducted with three households to understand daily life and intersubjectivity, self-perception about the relationship between subjects, nature and the cosmos, through generational analysis.

\subsection{Mayan world: dynamic macro-regional analysis}

The "Mayan World" is shaped by México, Belize, El Salvador, Guatemala and Honduras. Mexico integrates 241, $784 \mathrm{~km}^{2}$ within the states of Chiapas, Campeche Quintana Roo, Tabasco and Yucatán [5]. Its features are an amazing landscape, warm weather, extensive jungle and beaches in the Gulf of Mexico, the Mexican Caribbean or the Pacific Ocean. Ideal features to be designed as ultimate touristic destinations are building hotels, thematic parks, pubs, and resting places.

The activities along "The Mayan Route" are part of a recent creation, the Regional World Mayan Programme in 2011, the objective of which is:

"The strengthening of Mayan Region, on actions and strategies to improve touristic inputs in sustainable touristic development framework, with the participation of public and private sectors with local communities" [5].

Through: 1) building the infrastructure for service, railways and telecommunications that also connects all states on the Mayan route with the rest of the world; 2) promoting tourism investment in different levels and sectors; 3) promoting sustainability.

However, the intense promotion of first conventional tourism and then alternative tourism has caused high impact in this macro-region.

Firstly, cultural marginalization, because promoting Mayan culture leads to abandoning other important cultures like Olmec. Moreover, only one Mayan predominated, the Yucatec, other variations are excluded. Lastly Mayan culture also is less important in a traditional worldview in a globalization context [9]. The most important symbols are the pyramids, some drinks and traditional food and dress, and daily lifestyle is ignored. 
Secondly, there has been no alleviation of poverty. In macroeconomic terms, 20 years ago the index marginalization showed no change in the states (see Table 1). Major poverty areas are concentrated in Chiapas, and there is less poverty in Quintana Roo.

Thirdly, environmental problems are great, for example, in Cancun and Yucatan that sees over-densification in rural areas; water and air pollution, forest and soil degradation, and endangered wildlife. For more details, see [10, 11].

Table 1: Poverty in the "Mayan World" (adapted by [12]).

\begin{tabular}{|l|c|c|c|c|c|c|}
\hline State & \multicolumn{3}{|c|}{ Marginalization index } & \multicolumn{3}{c|}{ Marginalization grade } \\
\cline { 2 - 7 } & $\mathbf{1 9 9 0}$ & $\mathbf{2 0 0 0}$ & $\mathbf{2 0 1 0}$ & $\mathbf{1 9 9 0}$ & $\mathbf{2 0 0 0}$ & $\mathbf{2 0 1 0}$ \\
\hline Campeche & 0.47741 & 0.70170 & 0.43357 & High & High & High \\
\hline Chiapas & 2.36046 & 2.25073 & 2.31767 & Very high & Very high & Very high \\
\hline Tabasco & 0.51677 & 0.65540 & 0.47240 & High & High & High \\
\hline Quintana Roo & -0.19119 & -0.35917 & -0.41774 & Medium & Medium & Medium \\
\hline Yucatan & 0.39959 & 0.38133 & 0.42295 & High & High & High \\
\hline
\end{tabular}

\subsection{Lacandon rainforest: nature space and struggle}

The Lacandon rainforest is situated in the east of Chiapas (see Figure 1) and includes the municipalities Ocosingo, Las Margaritas, Marques de Comillas, Maravilla Tenejapa, Benemérito de las Américas and a little part of Palenque, Altamirano and Chilón [13]. It is a big mosaic of ecosystems with evergreen forest, coniferous forest and cloud forest, and a big collection of cultures and which constructs the natural space use [14].

Nevertheless, it is a regional space with a complex social, ecological and agrarian situation, caused by two very important institutional and official Declarations.

Firstly, the Agrarian Declaration by ex-president Luis Echeverria, who tried to attend to the pressure of land tenure of migrants or ancestral settlements [15], decided to reject land use planning and defined the Lacandon Community Zone (CZL) in 1972 with 66 lacandon households assigned 614,321 ha in three settlements: Naha, Metzabok and Lacanjá Chansayab [14]. Then in 1979 another settlement of choles and tzeltales households was recognized with property rights in this area [13]. However this assignation was unequal, because other settlements had petitioned agrarian regularization fifteen years ago without an answer from the state, therefore, they became irregular after the 1972 Declaration.

Secondly, the Ecological Preserved Declaration by ex-president José López Portillo, who joined international conservationist pressure to preserve the jungle, decided, in 1978, to reject the creation of PNA of Reserve Biosphere Montes Azules (REBiMA) whose polygon overlaps most settlements with CZL with 331,200 ha (see Figure 1).

Both are very important successes, because on the one hand it defined who can use natural resources, and on the other hand defined its use. Irregular settlements had to be removed from the Lacandon rainforest, and regular settlements can use 
the space but only with low farming, livestock, firewood, fishing but not hunting. The primordial use of the forest is for academic and scientific institutions and touristic, pharmaceutical, forest and energy markets [14]. Besides, communities have restricted access in their livelihood, paradoxically because they are blamed that their traditional activities jeopardize the Lacandon rainforest (see Figure 2).

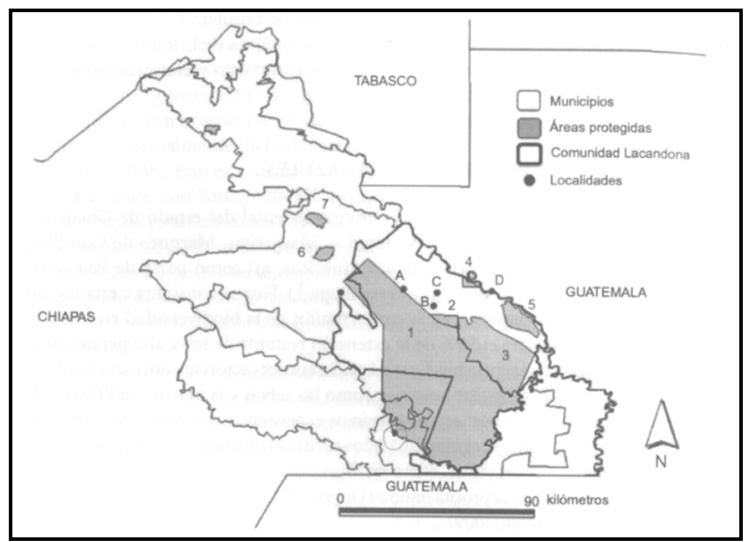

Figure 1: Lacandon rainforest territorial planning (adapted by [13]).

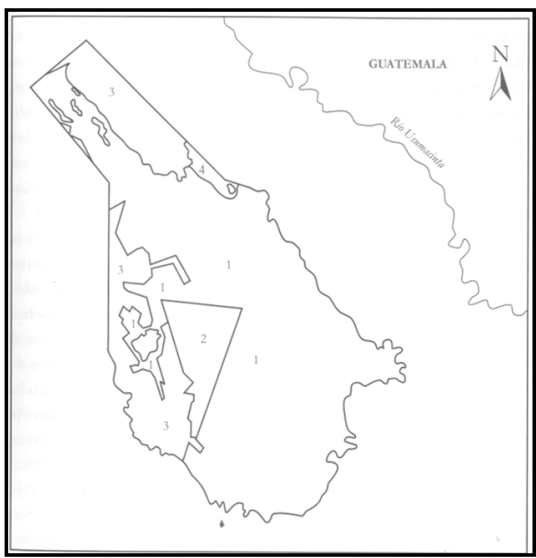

1 Restricted Use Area; 2 Protecting Area, 3 Natural Resources in Sustainable Use Area; 4 Traditional Use Area(Lacanjá).

Taken from SEMARNAT, REBiMA management Programme. National Ecology Institute Instituto 2000, p. 72

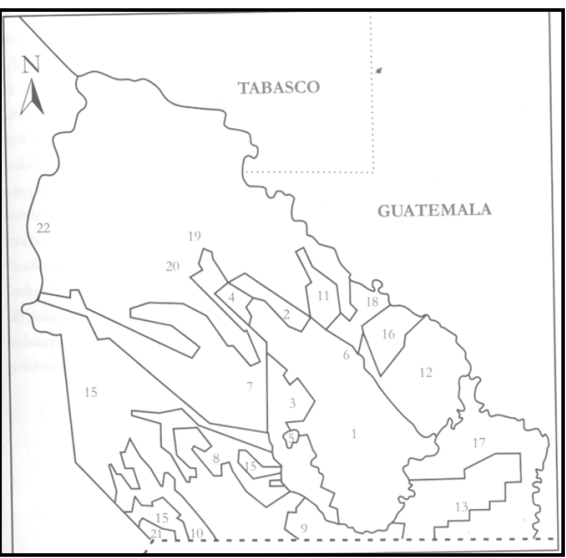

Areas in Nucleous Zone

1 Conservation and researching

2 Retrieval

3 Agricultural and Forestry

4-6 Cultural-Touristic
Areas in Influence Zone

7-10 Forest Preservation 11-13 Perennial Forest 14-17 Agricultural and Forestry

18-22 Cultural-Touristic

Taken from REBiMA Management Proposal, Tuxtla Gutierrez, Chiapas Government, 1990, p. 94

Figure 2: Livelihood Planning in Management Programme REBiMA (adapted by [14]). 
The above condition promotes conflicts and struggle among regular and irregular settlements and among the Lacandon people against the autonomy municipalities of Zapatist Army of National Liberation (EZLN). The first are the highest favored community in the Lacandon rainforest for their unequal right distributions. For instance, Lacanjá Chansayab and Emiliano Zapata (Miramar) are touristic places, first lacandon community, second zapatist filiation, and we can observe the following differences:

a) Access (state role): there is a railway that connects with the three most important touristic places in Lacanjá; on the other hand access to Miramar is more difficult, with unmade roads and touristic places are not connected.

b) Touristic dynamic (market role): there is less intervention by touristic agencies - with promotion and touristic affluence -in Miramar than in Lacanjá.

c) Livelihood (social dynamic importance): In Lacanjá, tourism is the main livelihood activity, in Miramar it is not so important.

In summary, the people of the Lacandon rainforest are not equal in their socioenvironment because they live in ecological marginalization with exclusion, deprivation and displacement in the territory, and then they are in environmental poverty:

"The incapability to access to natural resources for to get environmental services and products for livelihood [16] caused by human activities over ecological detriment [17] inside a specific context with particular asset and rights to different places [18]'”. [sic]

\subsection{Ecotourism in Lacanjá Chansayab}

The analysis of sustainable indigenous policies in the Lacandon rainforest showed three important, interrelated findings. 1) The PNAs restricted the relationship between humans and nature and their nutritional and spiritual subsistence, and imposes a new economic order-reification and 'stigmatization' of their traditional rituals; 2) PES restricts Lacandon people's use of natural resources, generating lack of land and food insecurity; 3) ecotourism has promoted the Reserves' landscape valuation in monetary terms, underestimating the traditional ecological Lacandon knowledge. Therefore, encouraging political and economic benefits' atomization has prompted internal conflicts and marginalization. Thus, natural and cultural heritage became natural and social capital stock.

Field work results reveal that Lacandon people perceived that environmental subsidies achieve simultaneous economic and social benefits. They assert, retrospectively, that poverty is eradicated, there are employment opportunities and the jungle is safeguarded. Nevertheless, on the one hand despite multi-sectorial governmental intervention of twenty years, poverty and environmental degradation persist, and on the other hand, the Lacandon people strongly depend on the subsidies and their capabilities are not developed to safeguard themselves and their environment. 
First, they have no sufficient income. Hence, they live in vulnerable and unstable conditions. Besides, land tenure is very important; being without land is linked to there being no chance of an owner's livelihood options [16, 18].

Since 1992, the communal property title connotes private property with the possibility that commoners can realize the legal trade of land with the State or Private Sector, a legal mechanism that safeguards the PES [19]. The Lacandon people say: "We believe that we are owners and guardians of the Jungle, however if we receive PESs, we are giving all our rights to the government and companies".

Second, transference streaming has diminished their human development and restricted their pursuit of a livelihood, and restricted community self-management [19]. However, it has prompted:

a) Consumption patterns are modified. From natural feed - self produced and expanded - to processed feed. This phenomenon is seen more in young people than elderly people.

b) Chronic-degenerative diseases increase. Mainly those related with stress and child malnutrition. Quality of life is depleted by the fact that physical activities are reduced. Diseases untreated by insufficient public service. Hence, the Lacandon people have to go out to other communities - using public or private services - or get no medical attention.

c) Null correlation between job and education. Streaming of multiple subsidies has not achieved favorable outcomes to motivate the youth to study in higher education and then diversify income source in large labor markets. This has recently happened and is contradictory to previous generations.

And, ecotourism has generated several problems.

a) Job and economic instability, unequal economic competition and there is job diversification.

b) In fact conventional mass tourism takes place with a negative environmental impact and trivializes indigenous culture [20].

c) There is no community model but rather private family monopolies [15].

Third, regarding the environmental aspects, the rainforest decreased by $72.5 \%$ in the last century [9]; from the perception of the Lacandon people, this phenomenon has generated environmental problems - climate variability and potential problems like air pollution, and a gradual decrease river levels - that generate impossible ecosystem resilience. Also the preservation strategies, PNAs, PES and ecotourism generated urban solid waste issues.

Last, gastronomic traditions, knowledge about the curative attributes of plants is being lost. Following the forced insertion to the international tourist market had led to the indigenous community meeting other lifestyles, exchanging behaviors and identities, in a reinvention form foreign to themselves, and from themselves to foreigners on how survivor strategically in a cultural heritage redimension [9], but always in a subordinate position [20, 21].

Consequently, cultural objects like vases, necklaces, drums, bags, robes and long hair that once were in daily use in Lacandon life no longer have this function. Instead they have acquired economic values by the Lacandon people and cultural values by tourists [21]. This culture of economic value is rejected by elderly people, who do not like to sell their traditions $[1,20]$. 


\section{Policies analysis: socio-spatial transformation}

The research interprets the reproduction of socio-spatial transformations, meaning and re-signification that different actors connote to spaces and cultural, natural and urban sets, as well as territory planning [22]. Like part of a process of structural and institutional change expressed in daily realities [23], the discursive construction on different scales and spaces continues [24]. In this sense, sociospatial transformation includes a global process constructed and represented with local realities.

Consequently, there are changes in social conditions, livelihoods, ancestral traditions, political organization, and the relation between human beings and their environment. This change underlies the power of unequal relations [25].

Hence, the relation among policies and socio-spatial transformation is about the institutional mechanisms that influence daily reality, in the lives of the Mayan people. Therefore, ecotourism policy implementation from regional to local level can be associated with:

a) Eco-territorial fragment in big way: nature preserved for ecotourism use in the global market; scientific bioprospection and energy use in PNAs; regularising an irregular settlement. In this way the most indigenous people have restricted use over natural space.

b) The restriction of natural resources represents socio-environmental inequality, because there are marginalizations: 1) ecological, since few people have or can use natural resources, the rest are displaced; 2) social, due to the same few people that can and have resources use, also can satisfy their basic needs - how food, dwelling and employment - are disposed through their livelihood; 3 ) economic, because tourism is a seasonal activity and touristic agencies are the most favored.

c) Symbolic representation of culture is resignified. First, the heterogeneity and diversity is replaced by homogeneity. Again, the most indigenous people are displaced. Second, bit by bit there are changes concerning the "use" in the iconographic sense of traditions; apparently those are more important to the tourist than for the Mayan people.

d) Finally, how the result of the three conditions described above, a struggling and fragmented community - ecological, social, economic and cultural - is in most cases evident or latent on the levels of inter-ethnic, intra-community, gender, and face to face. Also, social cohesion is limited.

Those situations are the effects of policies that combine the tourist market with a weakness in the political system. The tourist market is developed in a global logic, is a seasonal economic activity and is highly competitive. And the political system is related to the policies cycle:

1) Designed. For intrinsic features [26], the policies only include the solution of a little segment of the big spectrum of social and environment issues. The fact is that tourism is reified how operative panacea is only implemented from policies. This way, it is illogical. 
2) Implemented. This step is characterized for a top-down mechanism, with diffuse and ambiguous aims, and disarticulated strategies and weakness normative.

3) Evaluated. Official institutions do not ex-ante and/or ex-post evaluate. And, there is little research about the negative impacts of information before and after implementation of policies.

\section{Conclusions}

In this research, the aim was not a policies evaluation about ecotourism in Southern Mexico. This paper showed a policies analysis in a wider sense in that structural policies function was contrasted with empirical evidence. The main explicative conceptual framework was the power of relations over control and access to natural resource use, which are developed in an upward and downward spiral to a global-local and local-global scale in three spheres: the tourist market, the political system and indigenous communities among themselves and within themselves.

For this reason, one alternative - in a strict analytical level sense - can be proposed, the deconcentration and decentralization of power at different scales, which implied [27]:

1) Macro level, rights transferences rather than power privileges toward a local level. Also, equilibrium and power security.

2) Micro level, local decision-making should include: economic capital conducive to well-being improved; solid political structure in design appropriate regulations and social and environmental common ideology.

The above means symmetry in macro-micro relations of power toward social and environmental justice in a democratic context and then, improving or eradicating the overexploitation and reappropriation of social and spiritual material objects - land use, raw material immaterial objects - recreational items - and intellectual - traditional knowledge - of the poorest people. However, decentralization is possible under the two premises outlined above; otherwise it can result in negative effects.

The community fracture in Mayan communities is due to the antidemocratic mechanism of governmental intervention and abrupt insertion into the tourist market. In the underlying discourse of land security and nature preservation, indigenous people have underestimated - in political and economic terms but not cognitive - their cultural and innate abilities for natural resource management, inadvertently reaffirming their inability to safeguard their environment and they have accepted instructions by the hegemonic State and Market. Hegemony accuses them of being invaders or thieves in their own land $[1,20]$.

Hence, the absence or little consideration of local dynamics in policy implementation has a high impact on heterogeneous reality, thereby the treatment of the homogeneous generates inequality, then exclusion and then poverty [28]. 


\section{References}

[1] Coria, J. \& Calfucura, E., Ecotourism and the development of indigenous communities: The good, the bad, and the ugly, Ecological Economics, 73, pp. 47-55, 2012.

[2] Wearing S. y J. Neil, Ecotourism: Impacts, Potentials and Possibilities? Butterworth- Heinemann: Oxford, UK, pp. 1-286, 2009.

[3] Weaver, D. B., Comprehensive and minimalist dimensions of ecotourism, Annals of Tourism Research, 32(2), pp. 439-455, 2005.

[4] Cothran, D. A., \& Cothran, C.C., Promise or political risk for Mexican tourism, Annals of Tourism Research, 2 (25), pp. 477-497, 1998.

[5] Secretaría de Turismo (SECTUR) Programa Mundo Maya http://www.sectur. gob.mx/es/sectur/sect_Programa_Mundo_Maya. 2012.

[6] Secretaría de Medio Ambiente y Recursos Naturales (SEMARNAT) http://www.conanp.gob.mx/acciones/pdf/, 2012.

[7] Comisión Nacional para el Desarrollo de los pueblos Indígenas (CDI). http:/www.cdi.gob.mx/programas/2012/cdi-reglas-de-operacion-.pdf, 2012.

[8] Secretaría de Desarrollo Social (SEDESOL). Oportunidades para el desarrollo humano, http://www.oportunidades.gob.mx/Portal/work/sites /Web/resources/ArchivoContent/1783/Reglas_de_Operacion_Oportunidad es_2012_(DOF050712).pdf, 2012.

[9] Pastor Alfonso, M. A., Turismo y cambio en el entorno de los lacandones. Chiapas, México, PASOS. Revista de Turismo y Patrimonio Cultural, 10(1), pp. 99-107, 2012.

[10] Meyer-Arendt, K. J, Tourism development on the north Yucatan coast: Human response to shoreline erosion and hurricanes, GeoJournal, 4(24), pp. 327-336, 1991.

[11] Buzinde, C. N., Navarrete, D. M., Kerstetter, D. \& Redclift, M., Representation and adaptation to climate change, Annals of Tourism Research, 3(37), pp. 581-603, 2009.

[12] Consejo Nacional de Población (CONAPO). Índice de marginación por localidad,

http://www.conapo.gob.mx/es/CONAPO/Indice_de_Marginacion_por_Lo calidad, 2012.

[13] Durand S., L., Figueroa Díaz, F., G., Trench, T., Inclusión, Exclusión y Estrategias de Participación en Áreas Protegidas de la Selva Lacandona, Chiapas (Chapter 8). La Naturaleza en Contexto. Hacia una Ecología Política Mexicana, ed. L. Durand, F. Figueroa, M. Guzmán, CEIICHUNAM, CRIM-UNAM, Colegio de San Luis: México, México, pp. 237267, 2012.

[14] Vos, J., Camino del Mayab. Cinco incursiones en el pasado de Chiapas, CEICH-UNAM: México, pp. 1-299, 2010.

[15] Reygadas, L., Montoya, G., Hernández, F. y Velasco, F., Estilos de manejo $\mathrm{y}$ gestión de proyectos ecoturísticos en la selva lacandona de Chiapas, 
México (Chapter 2). Estudios multidisciplinarios en Turismo, ed. Guevara Ramos, R., SECTUR, CEST y RICIT: México, México, pp. 71-100, 2006.

[16] Scherr, S. J., A downward spiral? Research evidence on the relationship between poverty and natural resource degradation, Food Policy, 25, pp. 479-498. 2000.

[17] Liu, L., Environmental poverty, a decomposed environmental Kuznets curve, and alternatives: Sustainability lessons from China, Ecological Economics, 73, pp. 86-92. 2012.

[18] Reardon, T. \& Vosti, S. A., Link between Rural Poverty and the Environment in Developing Countries: Asset Categories and Investment Poverty, World Development, pp. 1495-1506, 1995.

[19] Rico García-Amado, L., Ruíz Pérez, M., Reyes Escutia, F., Barrasa García, S., \& Contreras Mejía, E., Efficiency of Payments for Environmental Service: Equity and additionally in a case study from a Biosphere Reserve in Chiapas, México, Ecological Economics, 70, pp. 2361-2368, 2011.

[20] Machuca R., J. A., Estrategias turísticas y segregación socioterritorial en regiones indígenas (Chapter 3). Turismo, identidades y exclusión, ed. Castellanos Guerrero, A. \& J. A. Machuca R., UAM-I/Juan Pablos: México, pp. 51-96. 2008.

[21] Van Den Berghe, P. L., Marketing Mayas. Ethnic Tourism Promotion in Mexico, Annals of Tourism Research, 22(3), pp. 568-588, 1995.

[22] Uribe, R., Paisaje, Narrativas y Experiencia: La Virtualización del Paisaje Maya, Estudios de la Cultura Maya, 40, pp. 227-265, 2011.

[23] Mc Lennan, C.J. Ritchie, B.W., Ruhanen L. M. \& Moyle, B. D. An institutional assessment of three local government-level tourism destinations at different stages of the transformation process, Tourism Management, 41, pp. 107-118, 2014.

[24] Richardson, T. \& Jensen, O. B., Linking Discourse and Space: Towards a Cultural Sociology of Space in Analyzing Spatial Policy Discourses, Urban Studies, 1(40), pp. 7-22, 2003.

[25] Durand S., L., Figueroa Díaz, F., G. Guzmán Chávez, M., La ecología política en México ¿Dónde estamos y para dónde vamos?, Estudios Sociales, 19(37), pp. 284-305, 2011.

[26] Aguilar Villanueva, L. F., La Hechura de las Políticas Públicas, Porrúa: México, pp. 1-442, 1992.

[27] Tacconi, L., Descentralización, forest and livelihoods: Theory and narrative, Global Environmental Change, 17, pp. 338-348, 2007.

[28] Sen, A., Nuevo examen de la desigualdad, Alianza: Madrid, España, pp. 137, 1992. 